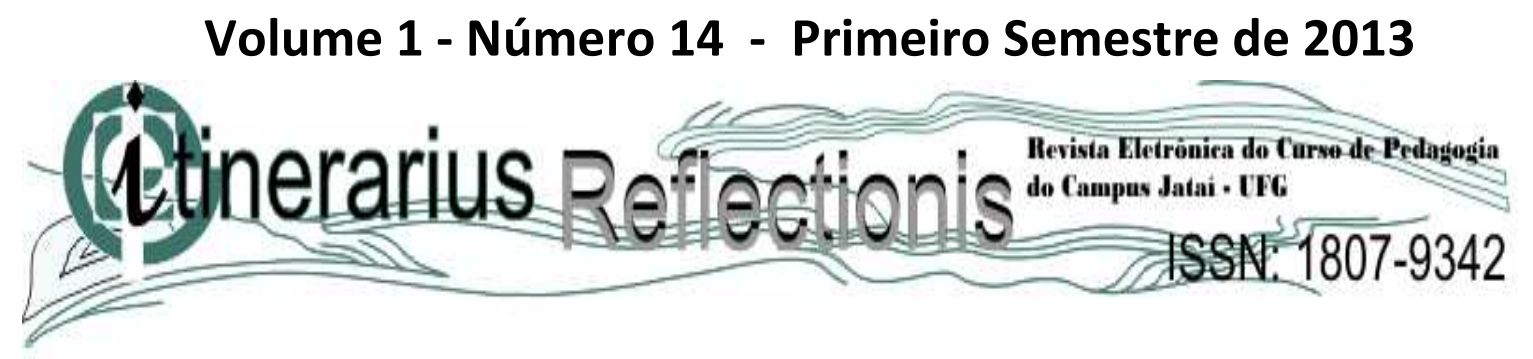

\title{
DIAGNOSTICO DA EDUCACAO AMBIENTAL E GEOGRAFIA NO ENSINO MÉDIO
}

Elisa Regina da Cruz. Graduando em Geografia pela UFG/ Campus Jataí, Bolsista PIBID Geografia 2012. elisa_gyn@hotmail.com

DRA. Zilda de Fátima Mariano. Professora titular da Universidade Federal de Goiás Campus Jataí-GO

Jane Karla Alves Cardoso. Graduando em Ciências Biologias pela UFG/ Campus Jataí, Bolsista Permanência no Laboratório Herbário.janekarla_cardoso@ hotmail.com

RESUMO: O objetivo desta pesquisa foi analisar o nível de conhecimento dos alunos sobre Educação Ambiental (EA), no Colégio Estadual José Feliciano Ferreira e imediações, em Jataí-GO, analisando a integração entre as questões ambientais no processo de ensino, nas aulas de geografia. A pesquisa foi desenvolvida com a turma do $3^{\circ}$ ano do $6^{\circ}$ período $\mathrm{C}$, do ensino médio noturno. O embasamento teórico da pesquisa discute sobre a EA, com a finalidade de compreender como surgiu a EA. Sendo assim, as primeiras conferências mundiais iniciaram durante a década de 70, para propor medidas e orientar a humanidades, a resolver os problemas ambientais, consequentes das explorações dos recursos naturais e destruição do meio ambiente. Essa pesquisa teve como método qualitativo, onde procurou descobrir por meio de observações, se o ambiente escolar inclui a EA nas aulas de Geografia. Analisando os dados por meio dos questionários percebe-se que os alunos possuem um conhecimento sobre EA. Em razão disso, para 8 alunos é uma forma de conscientização, 7 alunos afirmaram que ensina a cuidar do meio ambiente e 2 alunos apontaram que é manter o ambiente limpo. Em relação à prática de EA com a Geografia, 7 alunos responderam que sim, 7 alunos não e 3 alunos não soube responder. A EA pode servir como um instrumento para provocar mudanças nos alunos, em relação aos hábitos e assumir novas atitudes. Porém, deve ser lembrado que é um processo permanente. A EA necessita de tempo, para obter melhores resultados em relação à mudança de atitudes diante das questões ambientais. Para isso, a EA tem que ser trabalhada em todos os níveis de ensino, contribuindo para formação de alunos que se preocupa com a preservação do meio ambiente.

PALAVRAS-CHAVES: Educação ambiental. Meio ambiente. Ensino de Geografia 


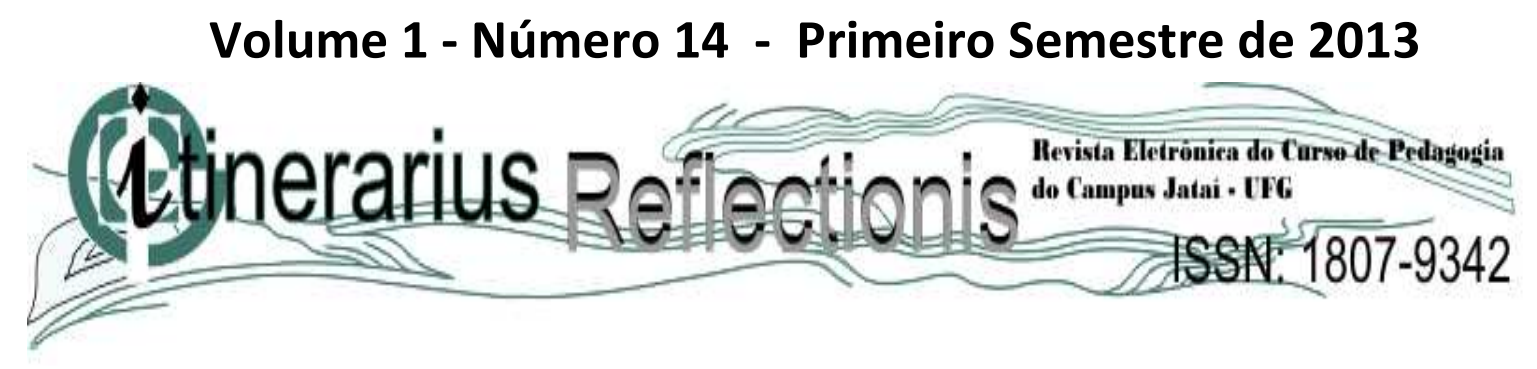

ABSTRACT: The purpose of this research was to analyze the students' knowledge level about Environmental Education (EA), at State School José Feliciano Ferreira, in JataíGO,analyzing the integration between environmental issues in the teaching process, ${ }^{+}$ Geography classes. The research was developed with the class of 3rd year of 6th period 2 overnight. The theoretical base of the research discusses about EA, in order to understand how the EA arise. Thus, the first world conference started during the 70's, to propose measures and guide the humanities, to solve environmental problems resulting from natural resources exploitation and environmental destruction. This research had as qualitative method, which sought to discover through observations, if the school environment includes the EA in Geography classes. Analyzing the data through surveys, it is clear that students have knowledge about EA. As a result, to 8 students it is an awareness way, 7 students answered that it teaches how to take care of the environment and 2 students claimed that it is to keep the environment clean. Regarding the EA practice with Geography, 7 students answered yes, 7 students said no, 3 students could not answer. EA may act as an instrument to bring changes on students, in relation to habits and take on new attitudes. But it must be remembered that it is an ongoing process. EA needs time to get better results in relation to attitudes change towards environmental issues. For this, EA has to be worked at all educational levels, contributing to the formation of students who care about preserving the environment.

KEY-WORDS: ENVIRONMENTAL EDUCATION. ENVIRONMENT. TEACHING GEOGRAPHY.

\section{Introdução}

Antes a sociedade se organizava no espaço e dependia da natureza para sobreviver, a sociedade dos dias de hoje busca na natureza seus interesses econômicos. Neste sentido, Tozoni-Reis (2004) afirma que nas últimas décadas do Século XX a Educação Ambiental (EA), passou a ser explorada como necessidade de criar meios para solucionar os problemas ambientais. A EA tem como objetivo formar pessoas que tem capacidade de discutir, tomar decisões, combater problemas e conflitos ambientais presentes na sociedade.

Dias (2004, p. 523) relata que "EA é um processo permanente no qual os indivíduos e a comunidade tomam consciência do seu meio ambiente e adquirem conhecimentos, valores, habilidades, experiências e determinação que os tornem aptos a agir e resolver problemas ambientais presentes e futuros". 


\section{Volume 1 - Número 14 - Primeiro Semestre de 2013}

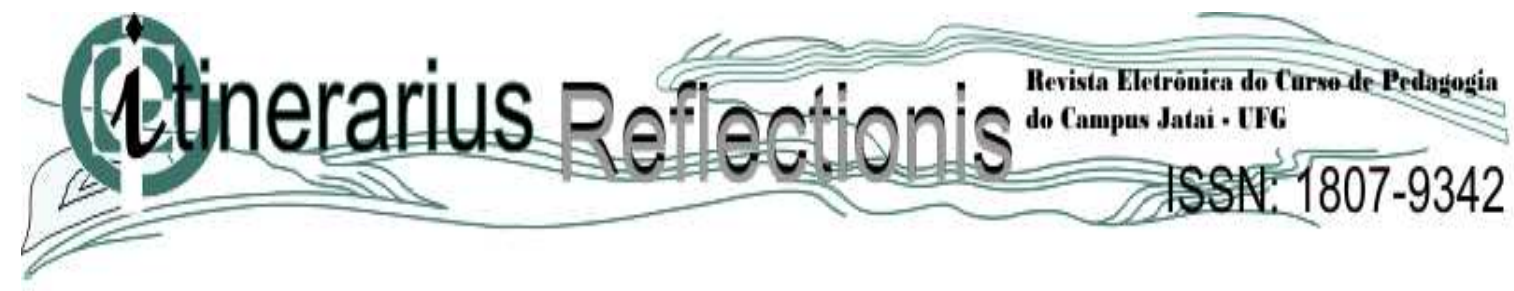

Como o autor aponta a EA precisa estar presente nas escolas, com um processo duradouro contribuindo para a construção de valores relacionados a pratica e mudança de hábitos. Assim sendo, a Geografia e as outras disciplinas precisam ensinar conteúdos relacionados com a EA, utilizando a interdisciplinaridade, contribuindo deste modo para formar alunos, que preocupe com a atual situação ambiental do nosso planeta.

Segundo Lima (2009, p. 16) “[...] os professores que atual em nossas escolas não estão preparados para trabalhar interdisciplinarmente [...]." Logo, os professores precisam ter um período para dedicar a pesquisa e estudos “[...] necessitaram de tempo extra para se aperfeiçoar em conteúdos das outras disciplinas, também."

Por meio do ensino de Geografia temos como finalidade proporcionar um conhecimento sobre EA, que seja capaz de propor aos alunos um conhecimento que contribui para formar cidadãos que praticam ações que favoreça o meio ambiente.

Desse modo, a pesquisa teve como objetivo analisar qualitativamente ser existe atividade de educação ambiental nas aulas de geografia no Colégio Estadual José Feliciano Ferreira (CEJFF), com os alunos do $3^{\circ}$ ano do $6^{\circ}$ período $\mathrm{C}$, do ensino médio noturno. Realizou-se levantamento de analise durante as observações nas aulas de Geografia e através do questionário para detectar qual o conhecimento dos alunos sobre Educação Ambiental.

\section{Breve histórico da EA}

Os problemas ambientais ocorreram principalmente por causa das atitudes do homem sobre a natureza, com a exploração dos recursos naturais. O rápido crescimento urbano das cidades gerou os diversos tipos de consumo da população. Para Coelho (2001) certamente as causas dos problemas ambientais do meio urbano, estão relacionados com o crescimento urbano e as alterações do modo de produção.

Assim Dias (2004, p. 210) relata que:

A satisfação das diversas necessidades humanas, associadas a um consumo excessivo e um rápido crescimento demográfico, tem exercido uma pressão crescente sobre o meio ambiente, quer seja diretamente, pelo excesso de exploração das riquezas naturais, ou indiretamente ao produzir quantidades excessivas de detritos em ralação à capacidade de absorção e depuração do meio ambiente. 


\section{Volume 1 - Número 14 - Primeiro Semestre de 2013}

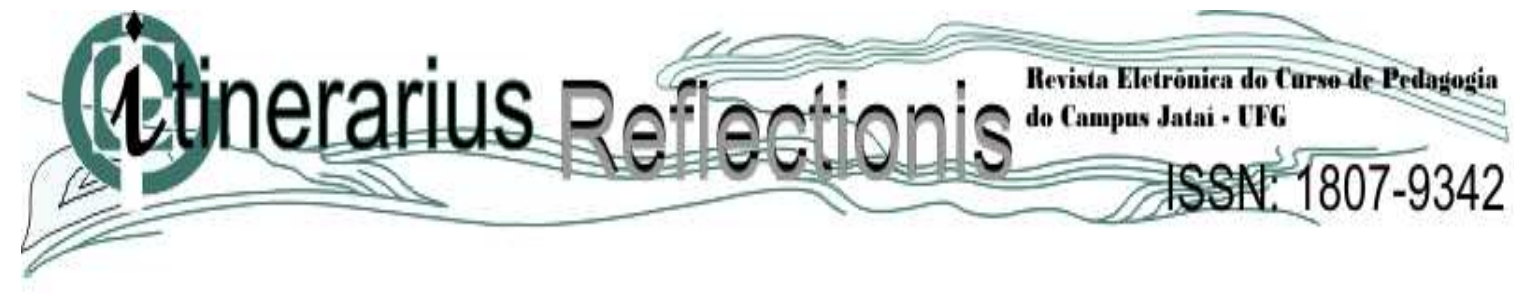

O modo de produção escolhido pelo homem moderno não tem proporcionado um equilibrado e uma interação entre homem e natureza. A sociedade atual é conduzida pelo modo de produção e consumo capitalista. Nesse sentido Maerchesini Jr (2012 p. 132) diz que,

\footnotetext{
a melhor definição para pensar a sociedade atual é a de uma "Sociedade de Consumidores", entretanto, não falamos do consumo natural e necessário para a sobrevivência, mas aquele consumo desnecessário, criado pela publicidade, indicado por símbolos e avalizado pela moda e pela padronização que o capitalismo propõe.
}

As discussões sobre a EA iniciam depois do mundo pós-guerra, com a finalidade de propor solução para os problemas ambientais provocados pela a ação do homem sobre a natureza. Em razão disso, a temática sobre a questão ambiental tem seu surgimento na sociedade contemporânea e alcança diversos campos do conhecimento, onde traz uma reflexão voltada principalmente paras as escolas nos dias atuais.

A década de 60 foi o limite para repensar sobre as grandes destruições do meio ambiente. Tozoni-Reis (2004, p. 3) "No ano de 1972 foi histórico para o movimento ambientalista mundial [...]." Iniciaram assim as primeiras discussões da EA, onde a primeira “[...] Conferência Mundial do meio Ambiente em Estocolmo (Suécia) [...]," com o comprometimento de introduzir na agenda internacional estudos sobre educação ambiental sendo um grande marco mundial.

Nessa concepção, aponta Guimarães (1995, p. 17) “em nível mundial, a questão ambiental ganhou grande repercussão com a Conferência das Nações Unidas sobre o Meio Ambiente, realizada em Estocolmo, em 1972, sendo discutida também nesta conferência a questão da educação ambiental para o meio ambiente [...]”.

Conforme Tozoni-Reis (2004) em 1975 ocorreu o Seminário Internacional sobre EA em Belgrado, que estabeleceu o Programa Internacional de Educação Ambiental (PIEA) estabelecida pela Organização das Nações Unidas para a educação, a ciência, a cultura (UNESCO).

A carta de Belgrado impôs uma nova posição sobre as questões ambientais, principalmente a importância da educação ambiental. "Os objetivos da educação ambiental 


\section{Volume 1 - Número 14 - Primeiro Semestre de 2013}

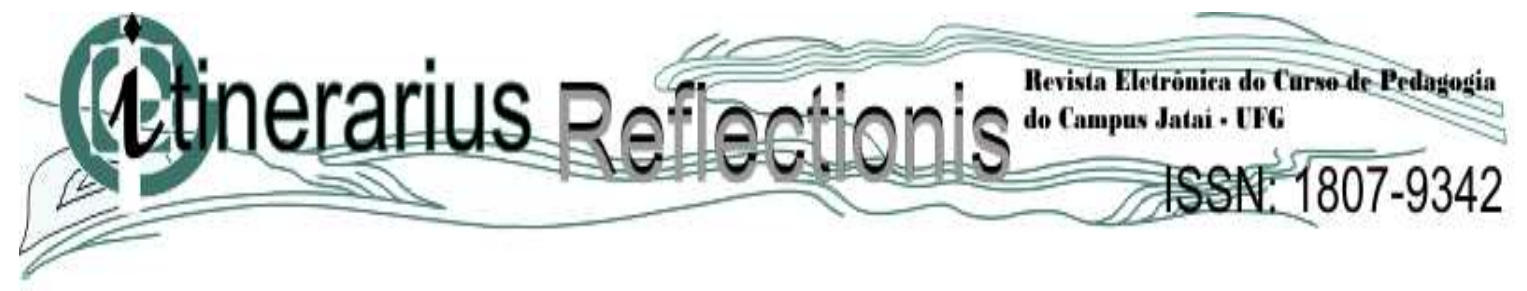

expresso são: conscientização, conhecimento, atitudes, habilidades, capacidade de avaliação e participação" (TOZONI-REIS, 2004, p. 4).

Para Dias (2004) nesse encontro criaram princípios para guiar e auxiliar a educação ambiental em todos os países. Teve como objeto estabelecer uma inovação no mundo, para oferecer uma melhor qualidade de vida a humanidade.

Na América Latina o movimento começa em 1976, em Chosica, Peru, Bogotá e na Colômbia, que traz a EA como a responsável pela transformação da sociedade. (GUIMARÃES, 1995).

Com o encontro de Belgrado aconteceu à primeira conferência Intergovernamental, a Conferência em Tibilise (Georgia - URSS) no ano de 1977, sendo fundamental para consolidar o Programa Internacional de Educação Ambiental (PIEA) que apresentava o objetivo de combater a crise ambiental que o mundo estava enfrentando. O PIEA foi fundamental para o desenvolvimento da EA (TOZONI-REIS, 2004).

Segundo Pedrini et al (2002) a Conferência de Tibilise tinha como obrigação fornecer uma educação formal e informal para a população em todos os níveis de idade, e fazer com que cada indivíduo participasse dos problemas ambientais do seu dia-a-dia. A EA teria que ter um enfoque interdisciplinar, propondo também nessa conferência a igualdade entre os países.

Segundo Oliveira (2010) as reuniões sobre EA só teve retorno após 10 anos da Conferência realizada em Tibilisi. De acordo com Pedrini et al (2002) em 1987 foi realizada a conferência em Moscou na (antiga União Soviética), nessa Conferência contou com a presença de quase trezentos educadores ambientais. No entanto, “[...] a EA deveria preocuparse tanto com a promoção da conscientização e transmissão de informação, como com o desenvolvimento de hábitos e habilidade, promoção de valores, estabelecimento de critérios e padrões e orientações para a resolução de problemas e tomada de decisões [...]." (PEDRINI et al, 2002, p. 29).

No ano de 1992 aconteceu a Conferência das Nações Unidas, que discutiram sobre o Meio Ambiente e Desenvolvimento, sendo realizada no Rio de Janeiro. Conforme Lima (2009, p.15) nessa conferência “[...] foram abordados temas como: o analfabetismo ambiental, 


\title{
Volume 1 - Número 14 - Primeiro Semestre de 2013
}

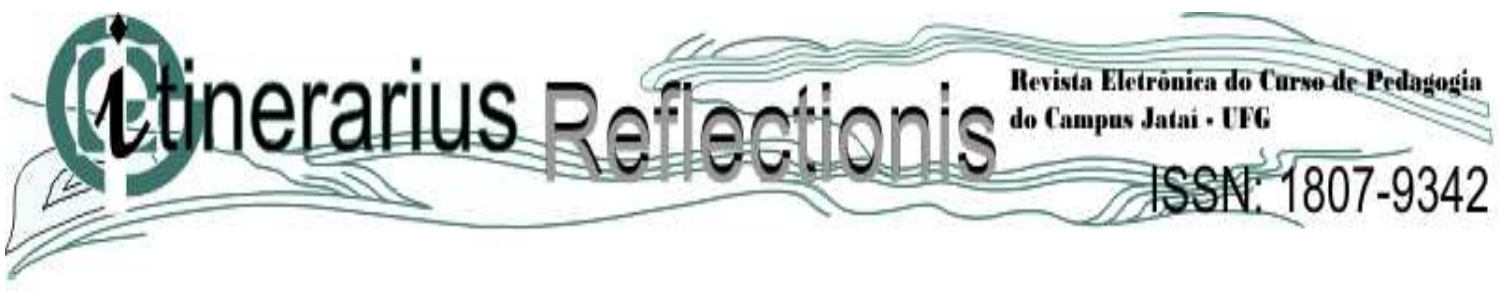

e a necessidade de se educar introduzindo o desenvolvimento sustentável".

Nesse sentido, aponta Dias (2004, p. 50) os principais objetivos a serem obtidos a partir dessa Conferência, foram:

\begin{abstract}
a) examinar a situação ambiental do mundo e as mudanças ocorridas após a Conferência de Estocolmo; b) identificar estratégias regionais e globais para ações apropriadas referentes às principais questões ambientais; c) recomendar medidas a serem tomadas nacional e internacionalmente, referentes à proteção ambiental através de política de desenvolvimento sustentado; d) promover o aperfeiçoamento da legislação ambiental internacional; e) examinar estratégias de promoção os países em desenvolvimento, entre outros.
\end{abstract}

\subsection{A importância da Educação Ambiental para a Geografia do Ensino Médio}

A educação ambiental traz uma grande contribuição para o ensino de Geografia, que é ensinar o aluno a valorizar e preservar o meio ambiente. Desse modo, afirma Guimarães (1995, p. 30) "em EA é preciso que o educador trabalhe intensamente a integração entre ser humano e ambiente e conscientize de que o ser humano é natureza e não apenas parte dela". Essa visão integradora permite que os alunos relacionem com o meio ambiente, compreendendo qualquer aspecto da natureza e adaptando, ou seja, exercendo atitudes que contribuiu para a melhoria do meio ambiente.

As escolas têm que desenvolver uma educação ambiental para todos, para ser trabalhado na Geografia e em qualquer outra disciplina em conjunto com a interdisciplinaridade. É preciso que as escolas passem a realizar atividades que seja capaz de orientar os alunos a discutir os problemas ambientais, ensinando a ocupar uma posição diferente no seu meio social, através de hábitos que mostra suas atitudes de preservação da natureza.

Pinesso (2006) discute que a interdisciplinaridade parte da construção de um projeto, que possibilita as ações entre professores, adotando idéias em conjunto e não conceitos a ser seguidos. Dessa forma, é necessário que as escolas trabalhem a educação ambiental a partir da interdisciplinaridade, fugindo de um ensino tradicional com conceitos prontos e fechados. Nesse caso, dando oportunidades para outras áreas do conhecimento a participarem de um 


\section{Volume 1 - Número 14 - Primeiro Semestre de 2013}

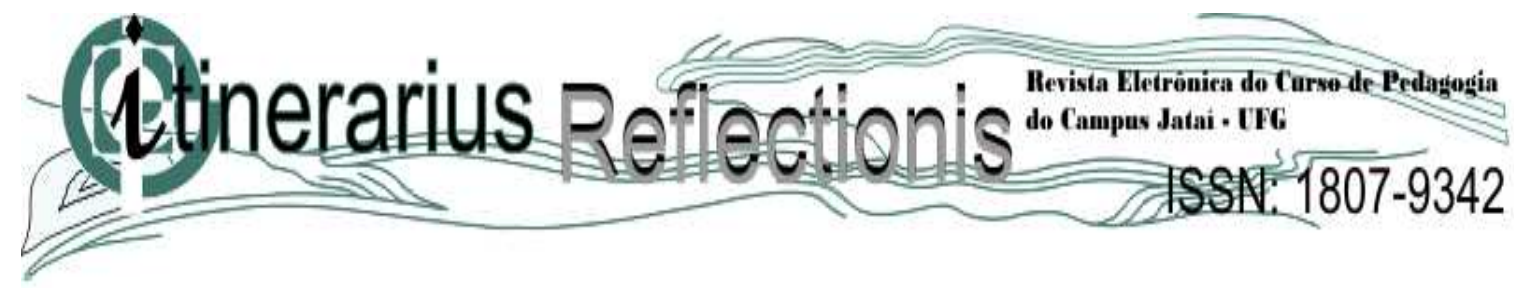

ensino crítico e construtivo, fazendo com que esses alunos saiam de uma aprendizagem enfadonha, passiva, para um ensino-aprendizagem mais ativo e reflexivo.

Guimarães (1995, p. 9) diz que EA precisa ser estabelecida nas escolas, pois "apresenta uma nova dimensão a ser incorporada ao processo educacional, trazendo toda uma recente discussão sobre as questões ambientais, e as conseqüentes transformações de conhecimento, valores e atitudes diante de uma nova realidade a ser construída".

A EA e a Geografia têm uma grande ligação, que possibilita estudar diversos problemas ambientais como: poluição, desmatamento, a produção do lixo, desperdício da água, etc. Qualquer um desses assuntos pode ser trabalhado em sala de aula, com auxilio de instrumentos como os audiovisuais, produção de cartaz, dinâmica, musica e outros.

Os educadores não podem deixar de fazer a sua parte, ensinar meios que ajude os educandos a construir conhecimentos, tomar decisões a respeito de suas atitudes e fazer escolhas sobre a sua vida. Zeppone (1999, p. 23), salienta a importância de construir mentes sadias:

Embora a educação no Brasil não seja prioridade, não podemos perder de vista a urgente necessidade de construirmos mentes sadias e convictas de sua participação na sociedade e no mundo, exercendo assim um dos direitos descritos em nossa Constituição (1998) que é o de viver em um ambiente ecologicamente equilibrado.

Cabe salientar que a EA deve ser discutida para resolver os problemas ligados ao meio ambiente, envolvendo a comunidade, os currículos escolares, e uma combinação entre os professores trabalhando com a EA em suas aulas. Deste modo "[...] a educação para o meio ambiente é, portanto, um assunto que deve ser tratado de maneira integrada, englobando a prática pedagógica e a representação social dos sujeitos envolvidos [...]," (TRAVASSOS, 2006, p. 16).

Para compreender o desempenho da Geografia nesse contexto ambiental, é preciso entender o seu objetivo, que é fazer com que os educandos entendam a noção de espacialidade e abranger também conhecimentos sobre os elementos naturais e sociais. A Geografia trata-se de uma visão de mundo, que busca compreender o comportamento da sociedade no meio em 


\title{
Volume 1 - Número 14 - Primeiro Semestre de 2013
}

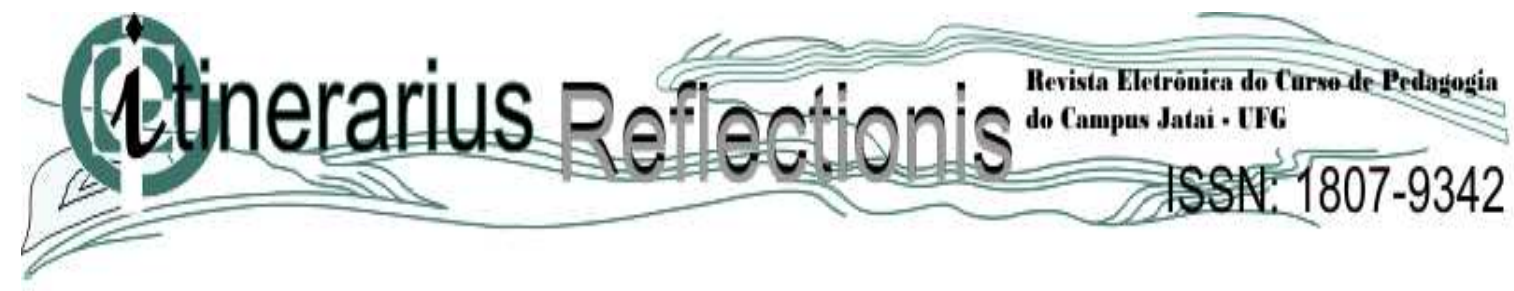

que vive. $\mathrm{O}$ estudo refere-se ao espaço e nas interações entre sociedade e natureza, como aponta Alves (2006, p. 134),

\begin{abstract}
nós, geógrafos, procuramos entender nossa sociedade, nosso mundo, a partir da análise do espaço geográfico. O espaço geográfico é produto das relações entre os homens com a natureza, e ao mesmo tempo é fator que interfere nas mesmas relações que o constituíram. O espaço é, então, a materialização das relações existente entre os homens na sociedade.
\end{abstract}

De acordo com os PCNs (2000, p. 64) a Geografia no ensino médio tem como propostas “[...] formas claras de práticas e reflexões capazes de proporcionar ao educando as condições de realizar a exercitação da pesquisa e da reflexão na disciplina". Cabe aqui dizer que é fundamental que trabalhe com os alunos nas aulas de Geografia as categorias da Geografia como: lugar, território, paisagem e globalização.

Partindo desse principio, os professores de Geografia tem que adotar medidas, para que os alunos compreendam essas categorias a partir de conceitos sobre: espaço, lugar, paisagem, território, globalização, meio ambiente e outros.

Assim, afirma os PCNs (2000, p. 65) “[...] essas são as questões ligadas a mundialização dos fatos culturais, políticos, econômicos e tecnológicos”. Com isso, pode concluir que o professor que trabalhe em suas aulas as categorias da Geografia, consegue realizar um ensino mais dinâmico, reforçando a participação dos alunos, pois o contexto do seu dia-a-dia passa a fazer parte das discussões das aulas, isso é possível através do processo de comparação dos fatos, contribuindo para assimilação dos alunos, no processo de ensino e aprendizagem. Desse modo segundo os PCNs (2000, p. 58) onde relata que:

a opção por conceitos e não por definições estanques é essencial para estruturação da Ciências Geográfica,que busca libertar-se da concepção de disciplina de caráter essencialmente informativo para se transformar numa forma de construção de conhecimento reflexiva e dinâmica, permitindo a criatividade e, principalmente, dando ao educando as necessárias condições para o entendimento do dinamismo que rege a organização e o mecanismo evolutivo da sociedade atual. 


\title{
Volume 1 - Número 14 - Primeiro Semestre de 2013
}

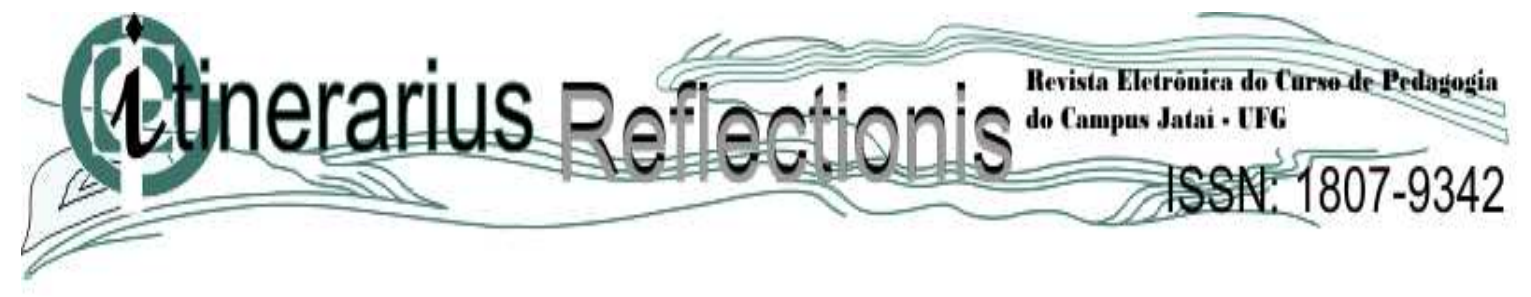

Faz-se necessário romper com as tendências de uma Geografia baseada na memorização. Para acabar com esse paradigma é preciso que professores adotem uma prática construtivista, que permite o aluno discutir suas idéias em relação ao conteúdo escolar.

Castrogiovanni (2004, p.18) aponta a prática construtivista:

\begin{abstract}
A epistemologia Construtivista e a pratica Relacional superam a simples memorização/descrição, aparecendo dissolvidas nos processos mentais mais elaborados, como a comparação/relação e análise; crítica. [...] compreendendo a geografia como um conjunto de conhecimentos produzidos/refletidos na interação sujeito-objeto, como resultado de processos de construção objetivo-subjetiva nas trocas cotidianas com a condição da vida como um processo de síntese, um resultado da interação.
\end{abstract}

Essa forma construtivista é determinada pela relação entre o individuo e o meio, permite ao educando a construção e organização dos seus conhecimentos, por meio de um mediador, ou seja, o professor. Deste modo, o professor ocupa papel importante para desenvolvimento da aprendizagem.

Neste contexto o ensino de Geografia tem que ajudar o aluno em uma aprendizagem que permite estudar o espaço, analisar a vida e o mundo, sendo capaz de perceber tudo que está em sua volta, construindo assim um conhecimento que auxilia em suas escolhas e atitudes.

Assim afirma os PCNs (2000, p.5) que o ensino de Geografia no ensino médio propõese:

[...] a formação geral, em oposição à formação específica; o desenvolvimento de capacidades de pesquisar, buscar informações, analisá-las e selecioná-las; a capacidade de aprender, criar, formular, ao invés do simples exercício de memorização. São estes os princípios, mas gerais que orientam a reformulação curricular do ensino médio e que se expressam na nova Lei de Diretrizes e Bases da Educação- Lei 9.394/96.

Segundo Castrogiovanni (2004, p.16) aponta que o ensino de Geografia precisa realizar um conhecimento que estabeleça em seus conteúdos uma educação critica, no entanto é necessário deixar as "práticas positivistas", pois essa contribui para empecer o ensino da forma critica. 


\section{Volume 1 - Número 14 - Primeiro Semestre de 2013}

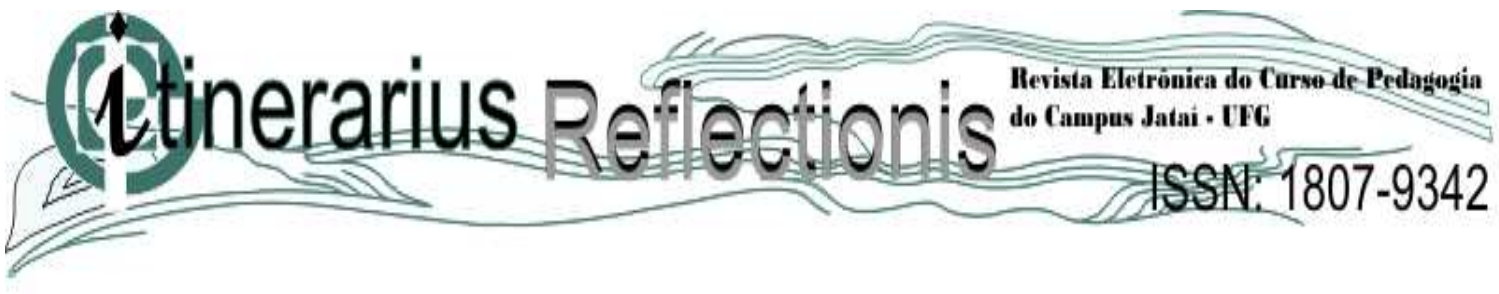

O conhecimento adquirido tem que ajudá-lo a compreender o espaço local e sua cultura, onde possibilita comparar a sua realidade com outras realidades. Cavalcante (2002, p. 12) salienta que:

[...] O trabalho de educação geográfica na escola consiste em levar as pessoas em geral, os cidadãos, a uma consciência da espacialidade das coisas, dos fenômenos que elas vivenciam, diretamente ou não, como parte da história social. O raciocínio espacial é importante para realização de práticas socioespaciais. As práticas sociais cotidianas são espaciais, pois elas têm um componente espacial que ao mesmo tempo em que movimenta essa prática sofre as suas consequiências; ou seja, há, nesse entendimento, um movimento dialético entre as pessoas em geral e entre elas e os espaços, formando espacialidade.

De acordo com Reichwald et al (2003, p, 169) "o ensino médio constitui a etapa final do ensino básico. É, portanto, o momento em que devem ser consolidados, complementados e aprofundados os conteúdos de aprendizagem que foram desenvolvidos no ensino fundamental".

Partindo desse princípio, nas aulas de Geografia é possível trabalhar com os alunos conteúdos que contribua para a reflexão sobre os problemas do meio ambiente. A Geografia permite estudar as diversas transformações que ocorrem no espaço. Logo, cabe ao professor orientar os alunos sob uma análise critica. Sabemos que a educação é a responsável por mudar as pessoas, é o meio que temos para construir conhecimentos e ser instruídos para tomar decisões certas.

Para concluir essa etapa de estudo no ensino básico, a Geografia tem que ocupar uma posição de leitura do mundo, por isso que EA tem que estar presente nas aulas de Geografia, pois ela permite estudar principalmente as relações homem e natureza e os problemas que afeta o meio ambiente.

Alves e Oliveira (2008, p. 12) "os desafios impostos de forma geral e especifica aos professores/as de Geografia são grandes. Há que se trabalhar com valores e comportamentos, tais como: solidariedade, cooperação, respeito mútuo, além de estimular uma visão global e crítica das questões ambientais, [...]”.

Para que haja esse desenvolvimento é preciso que todos tenham consciência de suas atitudes, seja político, educador, sociedade, etc. Nessa perspectiva, Oliveira (2008, p.42) 


\section{Volume 1 - Número 14 - Primeiro Semestre de 2013}

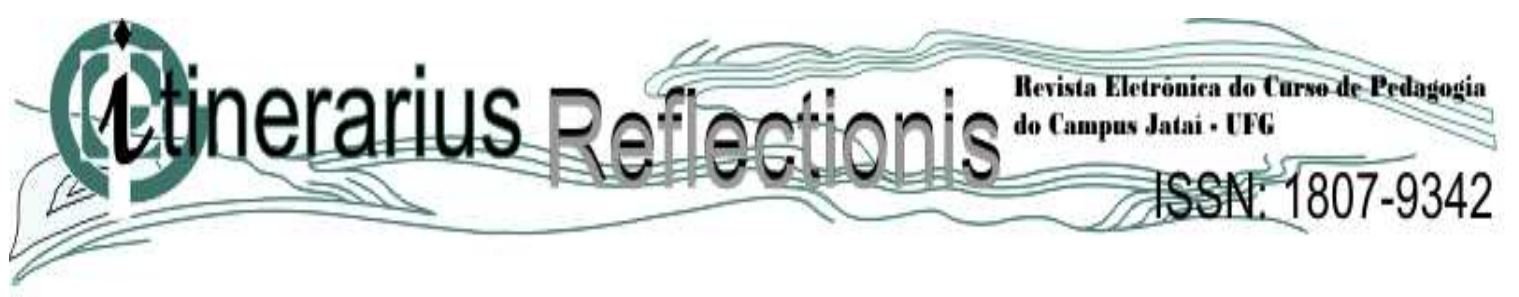

descreve que "a Educação cumpre um papel fundamental frente ás necessidades da nossa época histórica. Época que exige uma formação humana integral, a formação que propicie a vivência de valores e da ética do cuidado planetário". A educação deve preparar as pessoas com valores pessoais e éticos, e torna necessário o estudo da educação ambiental na formação de crianças e jovens.

\section{Material e Metodologia}

2.1 Material, localização da área de estudo

O estudo foi desenvolvido no CEJFF com uma turma do $3^{\circ}$ ano do $6^{\circ}$ período $\mathrm{C}$ noturno, situado na rua Miranda de Carvalho, n. 1406, centro da cidade de Jataí -GO (Mapa 1).

Mapa 1- Localização da área de estudo

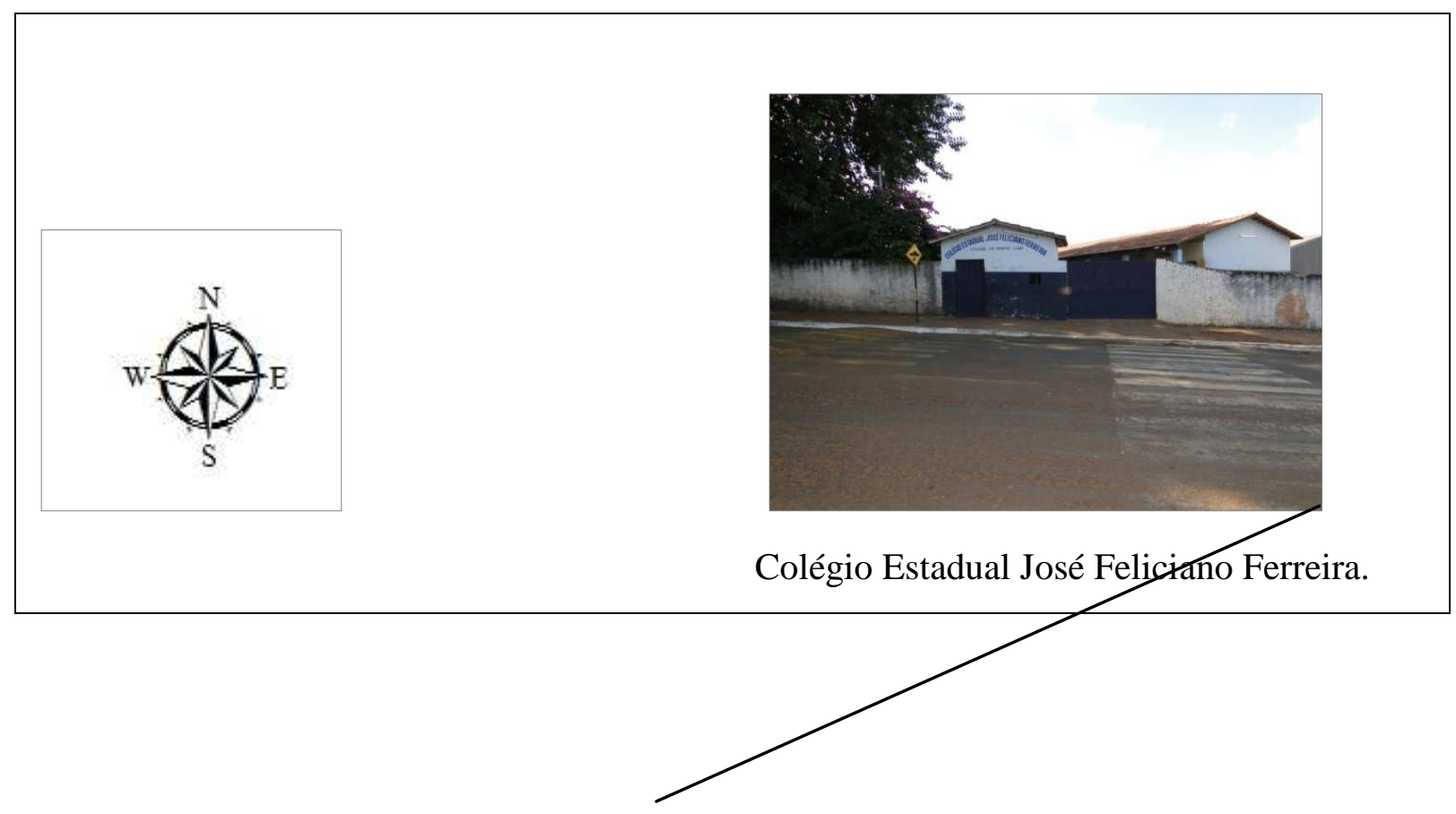




\section{Volume 1 - Número 14 - Primeiro Semestre de 2013}
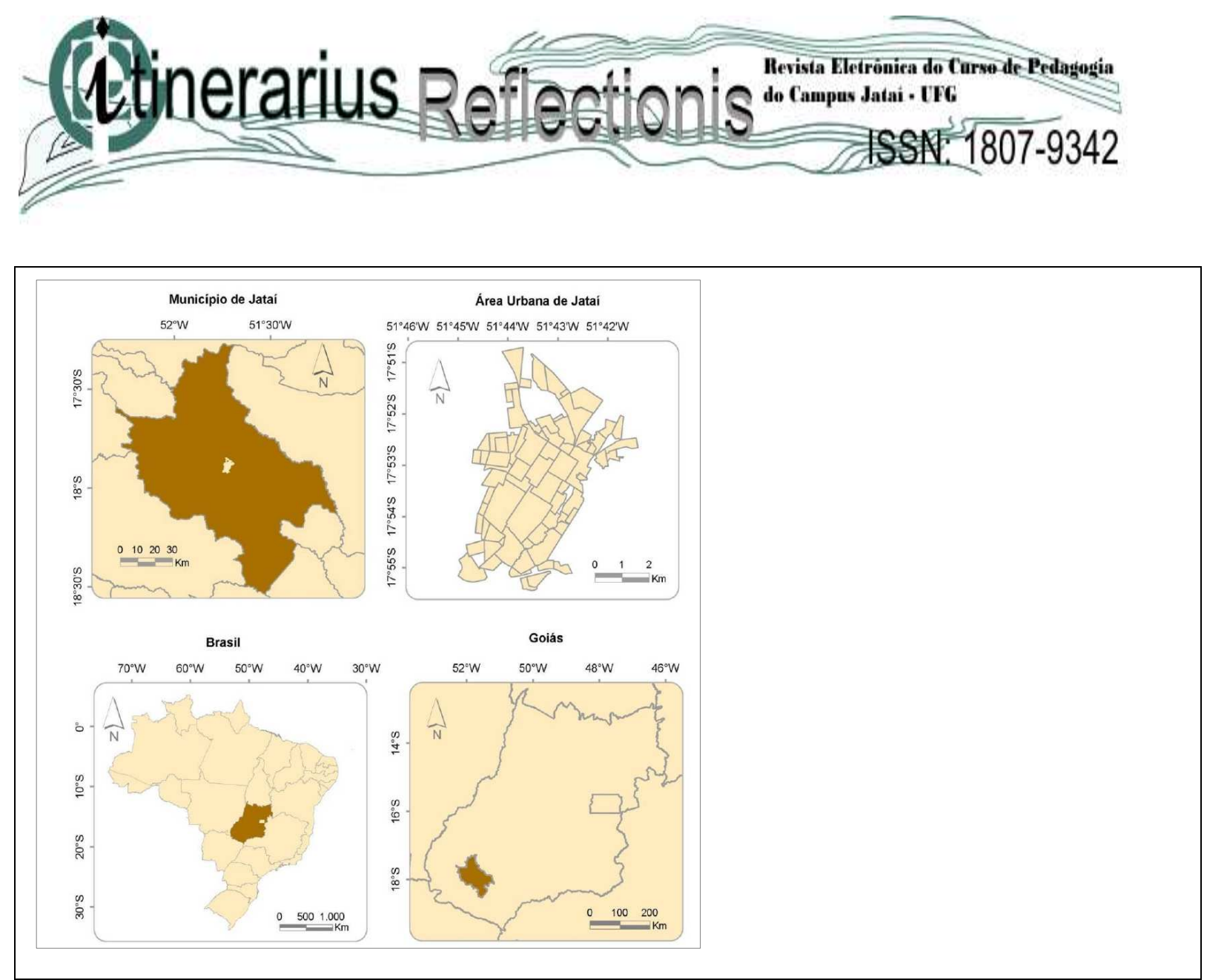

Fonte: Silva (2007) adaptado por Machado ( 2012)

\subsubsection{Metodologia}

A pesquisa foi desenvolvida no colégio Estadual José Feliciano Ferreira Jataí-GO, com os alunos do $3^{\circ}$ ano do $6^{\circ}$ período $\mathrm{C}$ noturno, por meio de um estudo de caso, que procurou analisar qual a situação da educação ambiental no ensino de Geografia.

Para realizar a análise da área do colégio, partiu da compreensão da realidade, baseada no método qualitativo por meio da fase exploratória que "[...] podem ter origem no enxame da literatura pertinente, poder ser fruto da observação [...]," (LÜDKE E ANDRÉ, 1986, p. 21).

O método qualitativo permitiu trabalhar de forma exploratória, explorando o local do colégio e suas imediações, realizando assim uma analise desse espaço que o aluno está inserido. A pesquisa qualitativa permite que o pesquisador use sua criatividade, assim Oliveira (2010, p.56) aponta que: 


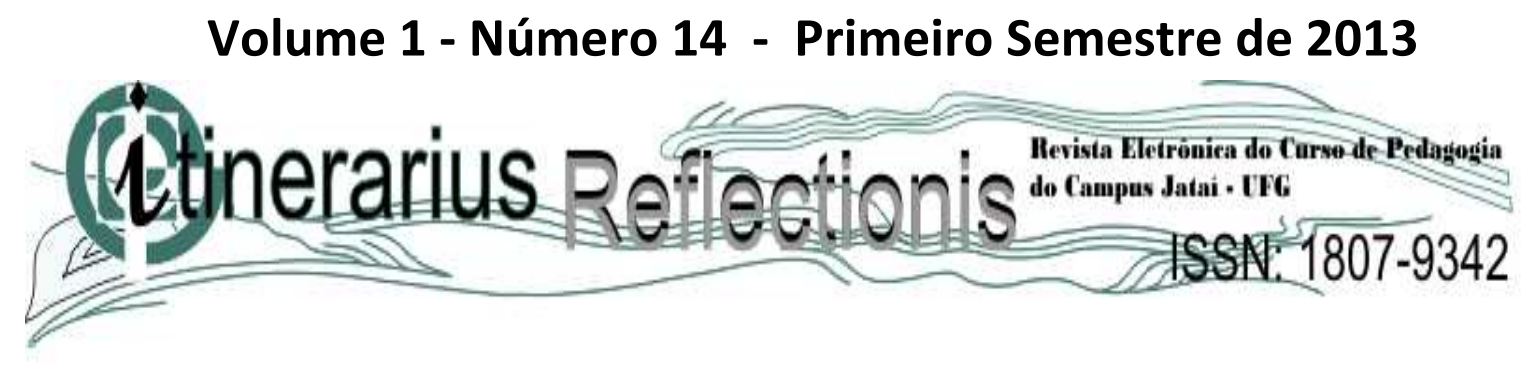

[...] esse tipo de pesquisa permite que se trabalhe sob o "mundo das idéias", considerando no processo o conhecimento e concepção tanto do pesquisador quanto dos sujeitos pesquisados e sua interação no próprio processo. Não se resume apenas ao olhar externo, à observação passiva da realidade, livre de qualquer comprometimento e posicionamento por parte do pesquisador, mas implica num constante olhar e olhar-se, compreender e compreender-se, perceber e perceber-se.

O contato do pesquisador é um dos pontos principais em uma pesquisa qualitativa, pois ele passa a conhecer a realidade estudada e o tema que escolhido. O pesquisador, utiliza de meios e atividades que estimulam a motivação dos participantes, pois Lüdke e André (1986, p.11). "a pesquisa qualitativa tem o ambiente natural como sua fonte direta de dados e o pesquisador como seu principal instrumento. Segundo os autores, a pesquisa qualitativa supõe o contato direto e prolongado do pesquisador com o ambiente [...]," (LÜDKE E ANDRÉ, 1986, p.11).

Assim uma pesquisa qualitativa torna possível compreender os fenômenos humanos e sociais e tem como agente principal, o pesquisador.

Para Bigotto (2008, p.79) o papel do pesquisador representa,

O pesquisador é parte fundamental na pesquisa qualitativa na qual ele deve preliminarmente, se despojar de todos os preconceitos, predisposição para assumir uma atitude aberta a todas as manifestações que observa, sem adiantar explicações nem se conduzir pelas aparências imediatas, a fim de alcançar uma compreensão global dos fenômenos.

\subsubsection{Coleta de dados}

No primeiro momento da pesquisa realizou um levantamento de fontes secundárias, ou seja, uma pesquisa bibliográfica, para levantamento de autores que discutem sobre o assunto, para analisar a realidade que a escola campo apresenta.

A pesquisa utilizou como recurso de coleta de dados a observação nas aulas de Geografia, onde foram observados os seguintes aspectos: o PPP do colégio, área do colégio, a existência de projetos de prática de EA, ligação da EA com o ensino de Geografia. 


\section{Volume 1 - Número 14 - Primeiro Semestre de 2013}

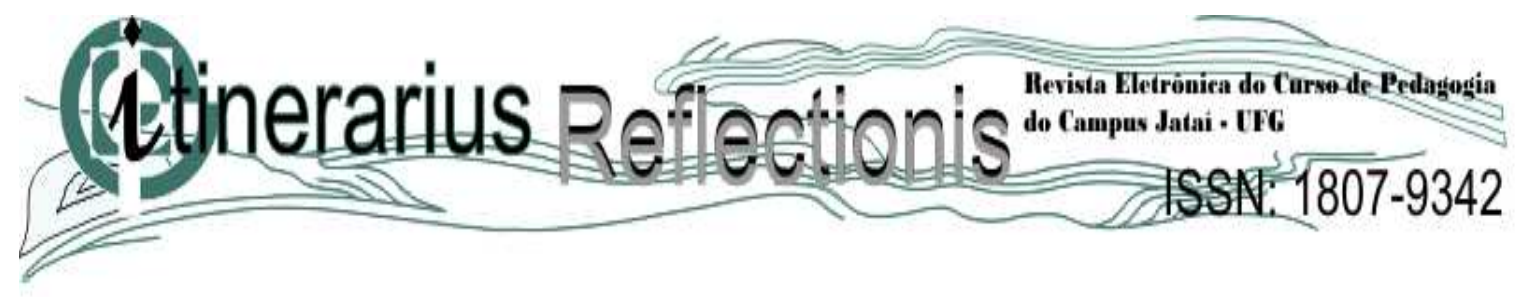

Em sala de aula as observações foram realizadas entre os meses de abril e maio de 2011, essas possibilitaram adquirir dados sobre a educação ambiental, onde verificou nas aulas a relação entre o ensino de Geografia com a educação ambiental.

A população pesquisada foi 17 alunos, do $3^{\circ}$ ano do $6^{\circ}$ período $\mathrm{C}$ do ensino médio, noturno do colégio CEJFF. Para esta população foi questionário aplicados para diagnosticar os conceitos que os alunos têm sobre EA.

Esse questionário foi composto por 6 perguntas, para Bigotto $(2008$, p. 82) “a utilização desta técnica não é a mais indica para uma pesquisa de caráter qualitativo, [...] mas esta não descarta a coleta de dados quantitativos, [...] estes dados podem mostrar uma relação mais extensa entre os fenômenos particulares"

\section{RESULTADOS E DISCUSSÃO}

Análises do questionário aplicado aos alunos do $3^{\circ}$ ano do $6^{\circ}$ período $\mathrm{C}$, noturno. No Gráfico 1 sobre a definição de EA, 8 alunos consideram "uma forma de conscientizar as pessoas, informando sobre como preservar a natureza e seus recursos, a educação ambiental, ensinar preservar o meio ambiente"; 7 alunos afirmaram que "ensina a cuidar do meio ambiente é por meio dela que recebemos orientação para mudar nossos hábitos" e 2 alunos apontaram que é "manter o ambiente limpo"

Assim o gráfico 1 observe as respostas dos alunos a) Aluno A: "é uma forma de conscientizar e ensinar as pessoas a preservar o meio ambiente e a natureza"; b) Aluno B: "é a orientação de como podemos melhorar a questão ambiental mudando nossos hábitos" e c) Aluno C: "educação ambiental é aprimorar os nossos conhecimentos e cuidados com o meio ambiente". Portanto confirma Dias (2004, p. 532) EA, "é um processo permanente, no qual os indivíduos e a comunidade tomam consciência do seu meio ambiente [...]”.

Gráfico 1 As definições sobre educação ambiental do $3^{\circ}$ no do $6^{\circ}$ período $\mathrm{C}$, noturno 


\section{Volume 1 - Número 14 - Primeiro Semestre de 2013}
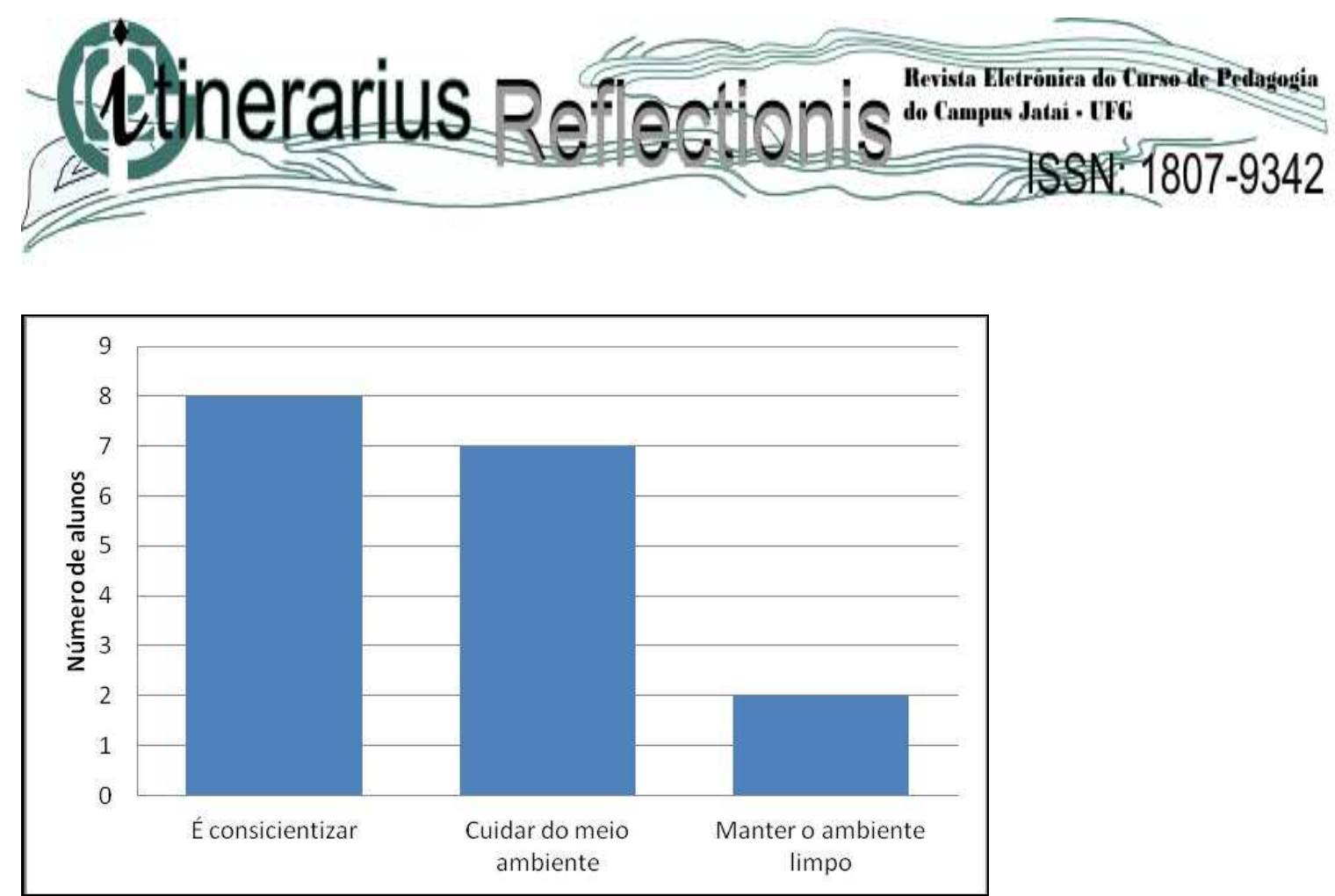

Fonte: Cruz, (2012)

A forma como os alunos receberam orientação, sobre EA verificamos, que 7 alunos receberam orientação por meio do professor e da escola; 7 alunos pelos meios de comunicações como: TV e anúncios; 1 aluno pela internet; 1 aluno por livros e revistas, e 1 aluno não respondeu. Outro ponto importante para construção desse conhecimento é a interferência da família, que tem um grande papel na discussão com os filhos, sobre a importância de preservar o meio ambiente, (Gráfico 2).

Gráfico 2 - As formas como os alunos receberam orientação sobre educação ambiental, do $3^{\circ}$ ano do $6^{\circ}$ período $\mathrm{C}$, noturno

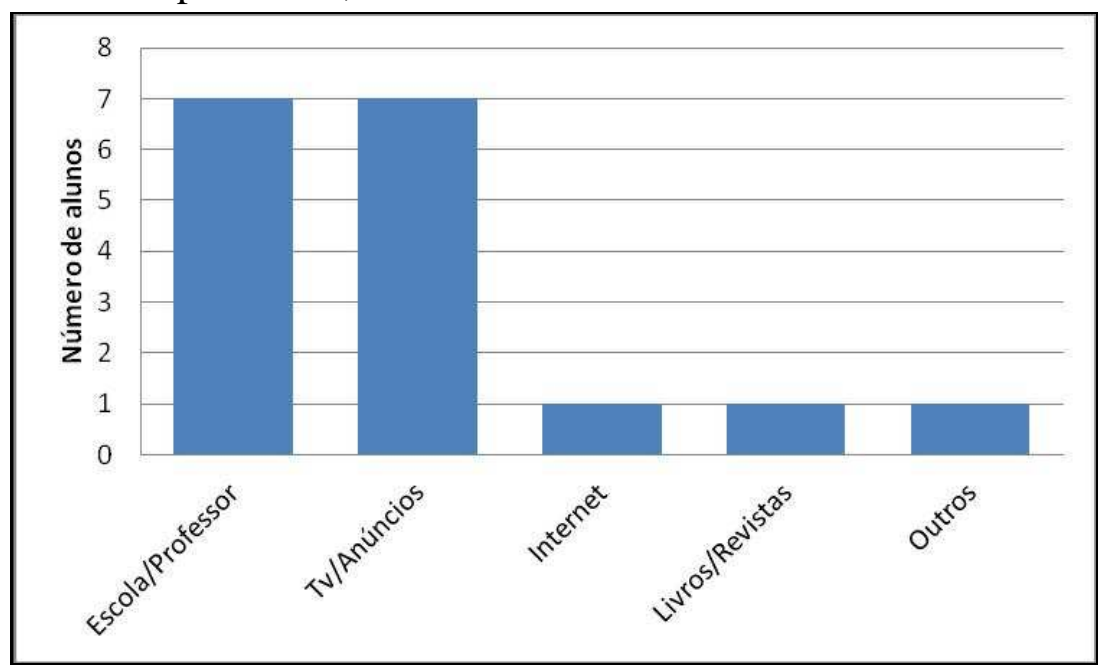

Fonte: Cruz (2012) 


\section{Volume 1 - Número 14 - Primeiro Semestre de 2013}

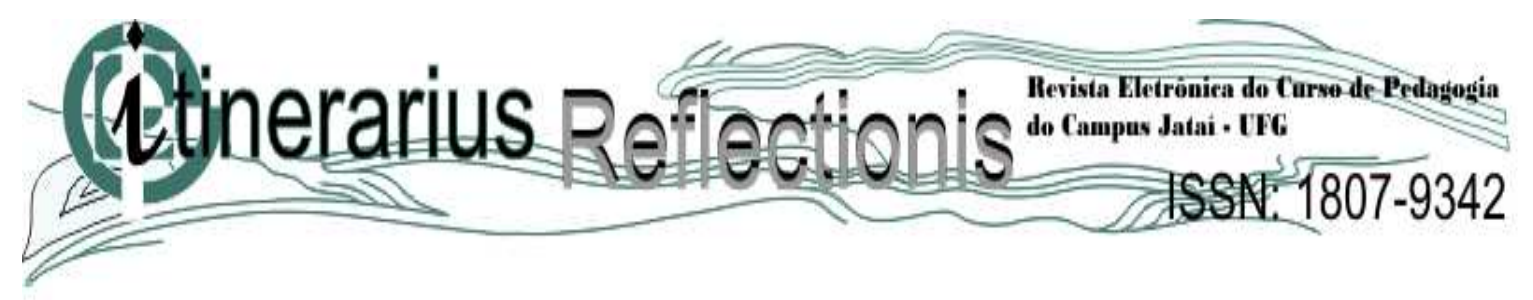

O Gráfico 3 apresenta qual o assunto em educação ambiental mais interessante, 8 alunos apontaram os assuntos sobre a reciclagem do lixo; 4 alunos por temas de como preservar o meio ambiente; 2 alunos todos os assuntos; 2 alunos sobre o aquecimento global e 1 aluno sobre o desmatamento.

Esses resultados são apresentados nos relatos dos alunos A, B e C, o aluno A: "a reciclagem do lixo, a curiosidade sobre esse lixo, como o planeta estará no futuro com a ação do homem"; aluno B: "sobre o meio ambiente e como preservar" o aluno C: "a reciclagem onde se inicia por um simples hábito de separar o lixo". Logo, é possível observar que a maioria dos alunos aponta como assunto interessante à reciclagem do lixo.

Gráfico 3 - Qual o assunto em educação ambiental, mais interessante para os alunos do $3^{\circ}$ ano do $6^{\circ}$ período $\mathrm{C}$ noturno

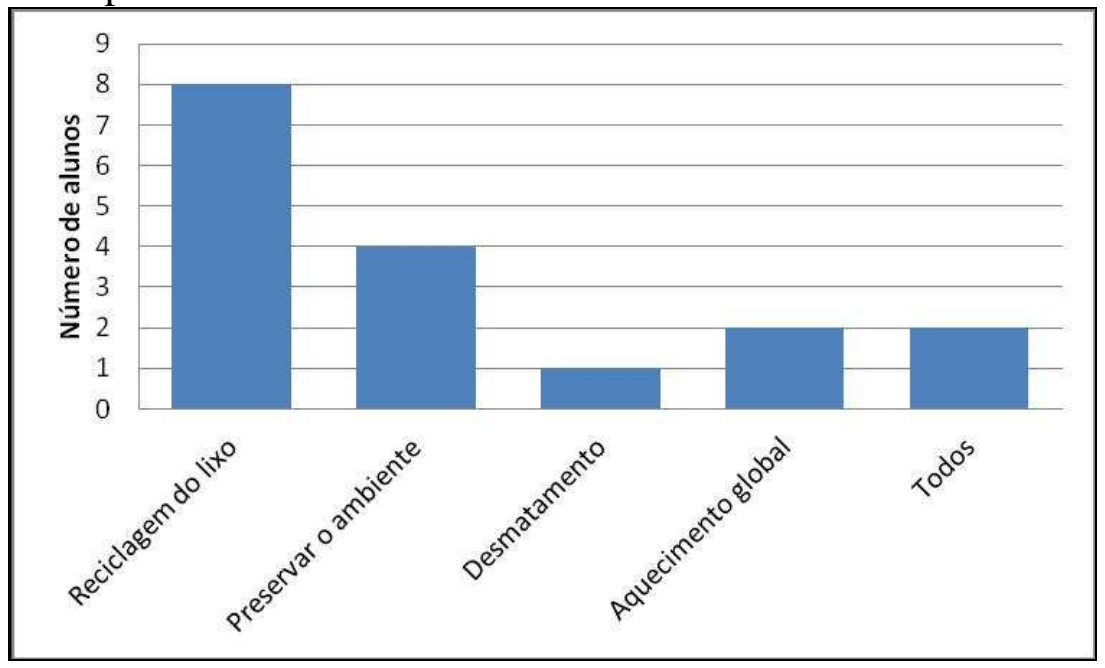

Fonte: Cruz (2012)

A educação ambiental é considerada importante para 15 alunos segundo relato deles "orienta na preservação do meio ambiente, a natureza precisa ser preservada para gerações futuras"; 1 aluno respondeu que acha "interessante" e outro aluno porque "conscientiza o que fazer com o lixo" Nesse caso, a maioria dos alunos, descrevem a sua importância na preservação do meio ambiente para outras gerações, (Gráfico 4). 


\section{Volume 1 - Número 14 - Primeiro Semestre de 2013}

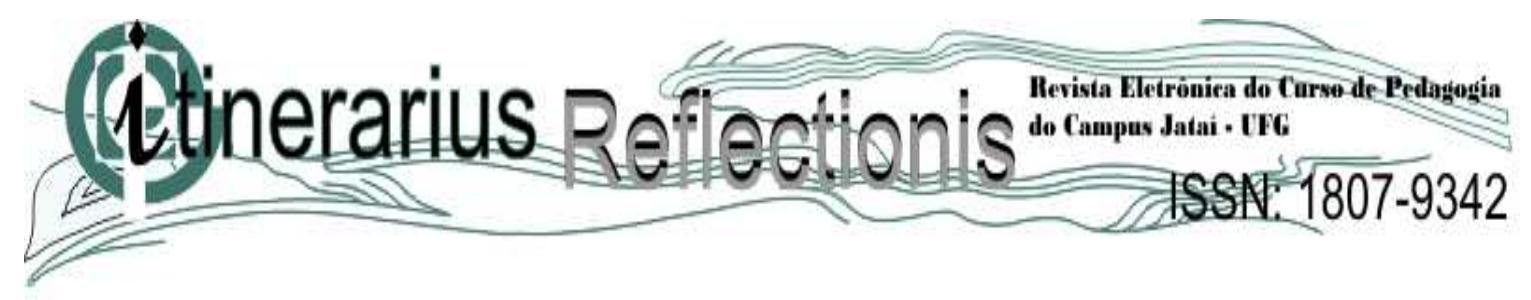

Gráfico 4 - Porque os alunos do $3^{\circ}$ ano do $6^{\circ}$ período $C$, noturno consideram importante a EA

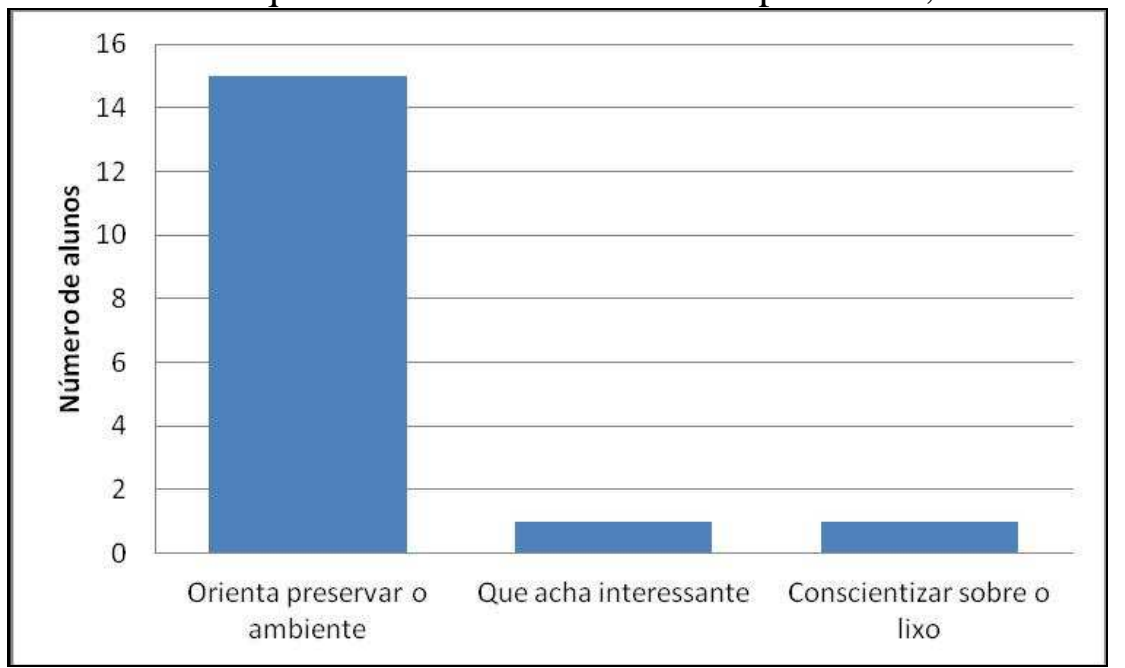

Fonte: Cruz, (2012)

Em relação se conteúdos da Geografia ministrados durante a escolaridade esteve relacionados com da prática educação ambiental; para 7 alunos responderam sim, 7 alunos não e 3 alunos responderam não saber sobre essa prática. A relação da EA com a Geografia contribui para a construção do conhecimento sobre as questões ambientais, assim o que e ensinado é absorvido pelo aluno, pois são acontecimentos que estão inseridos na realidade do aluno, ou de outra forma é transmitido pela mídia, jornal ou internet. Com isso é possível quebrar paradigmas que a Geografia é um estudo baseado na memorização, pois os PCNs (2000) de geografia no ensino médio coloca que o estudo de Geografia tem que, contribuí para a reflexão e análise, assim orienta a busca de informações sobre determinado assunto que foi estudado. (Gráfico 5 ). 


\section{Volume 1 - Número 14 - Primeiro Semestre de 2013}

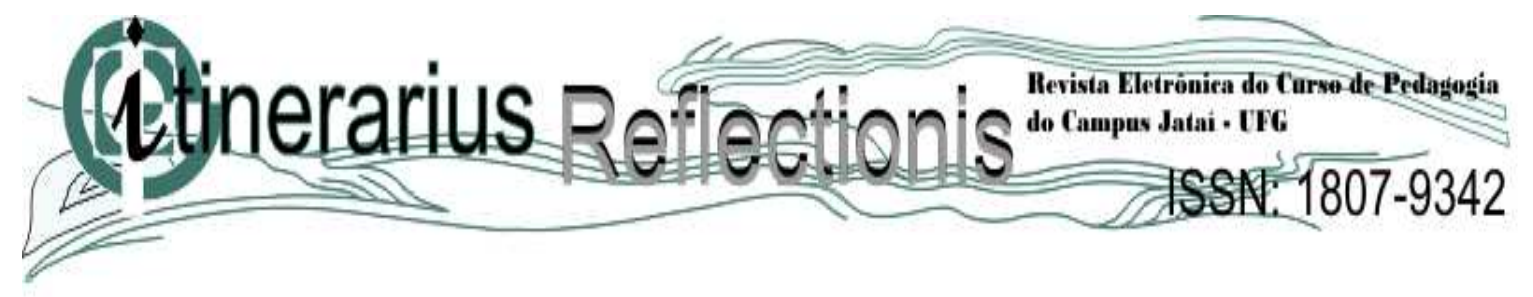

Gráfico 5 - Conteúdos de Geografia e a prática de Educação Ambiental dos alunos do $3^{\circ}$ ano do $6^{\circ}$ período $\mathrm{C}$, noturno

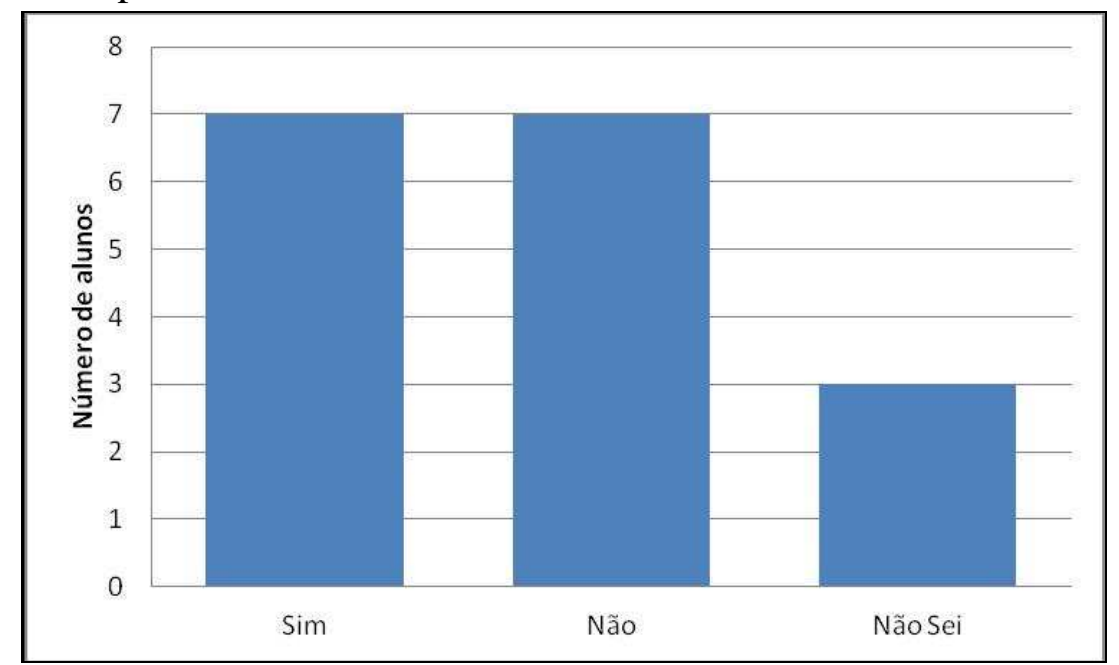

Fonte: Cruz (2012)

O Gráfico 6 mostra à opinião dos alunos em relação ao lixo no espaço do colégio e imediações, para 9 alunos "o lixo na escola e imediações são responsáveis pela poluição do meio ambiente" 3 alunos recomendaram que: "a escola necessita de uma coleta seletiva" , 3 alunos "a situação da escola e imediações não está tão ruim". 2 alunos, relataram que o lixo no colégio "é uma falta de consideração. Destacamos três opiniões dos alunos entrevistados:

aluno A: "tem sala que nem tem lixeira, quando os alunos chega pra aula as salas estão todas sujas de papel como que a escola quer que os alunos tem educação se escola nem tem consideração com os alunos eles acham que nos devemos estudar em uma sala suja, bagunçada isso é na primeira aula imagina no final da aula como que a sala vai tar. Quando cheguei pra sentar no meu lugar tive que catar lixo do chão pra sentar se não eu ia ficar em uma bagunça", aluno B: "na minha opinião mostra que nos mesmo fazemos, ou seja temos esta atitude de sujar a escola" e aluno C "a situação do lixo é pesimo por que está poluindo o nosso ambiente".

Gráfico 6 - O lixo no colégio e imediações, no ano de 2011 


\section{Volume 1 - Número 14 - Primeiro Semestre de 2013}
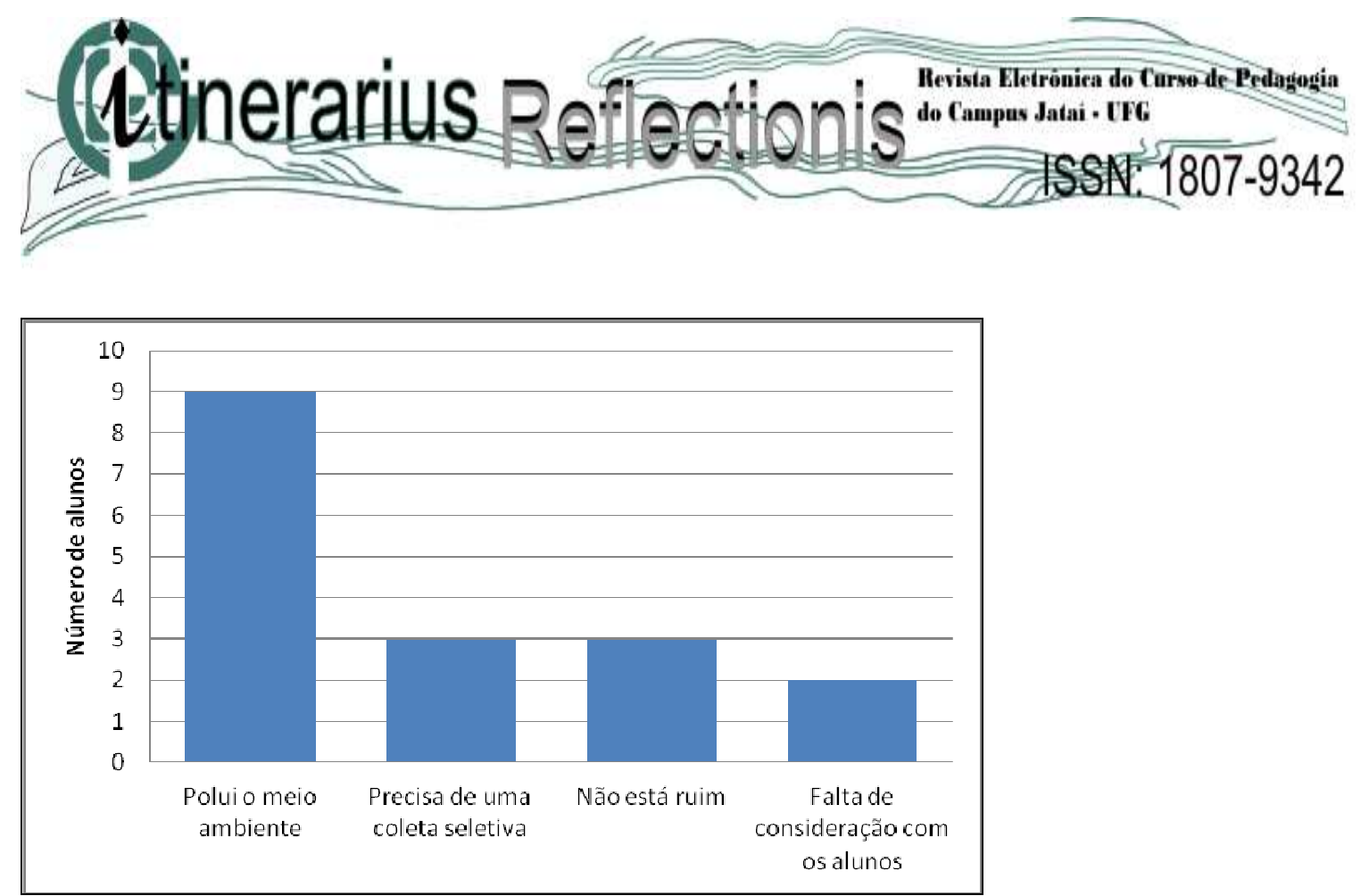

Fonte: Cruz, (2012)

\section{Considerações finais}

A EA não é impossível, mas para obter os resultados esperados, precisa ser trabalhadas por todos os professores do colégio, sendo realizada em todos os níveis de ensino. É importante que todos trabalhem em conjunto, e adote projetos voltados para EA. Confirmado por Pinesso (2006) discute o uso de projetos tem significado quando é construído a partir de um problema.

Os professores e a direção da escola devem reconhecer a importância de estar trabalhando as questões ambientais com os alunos, pois por meio dessa pesquisa foi possível verificar uma deficiência na falta de projetos e realização de interdisciplinaridade que envolve EA na escola campo.

No mundo de recursos audiovisuais é possível encontrar diversos recursos, onde professores encontram subsídios para trabalhar diversos temas, utilizamos o uso do vídeo como recurso didático, que contribuiu para a discussão sobre diversos temas.

Foi possível averiguar de acordo com os conceitos teóricos dessa pesquisa que os alunos apresentam conhecimentos para conceituar o que é educação ambiental.

O colégio precisa desenvolver atividades de EA, porque todos os alunos afirmaram gostar de atividades sobre o meio ambiente, sendo apontados diversos temas como: 


\section{Volume 1 - Número 14 - Primeiro Semestre de 2013}

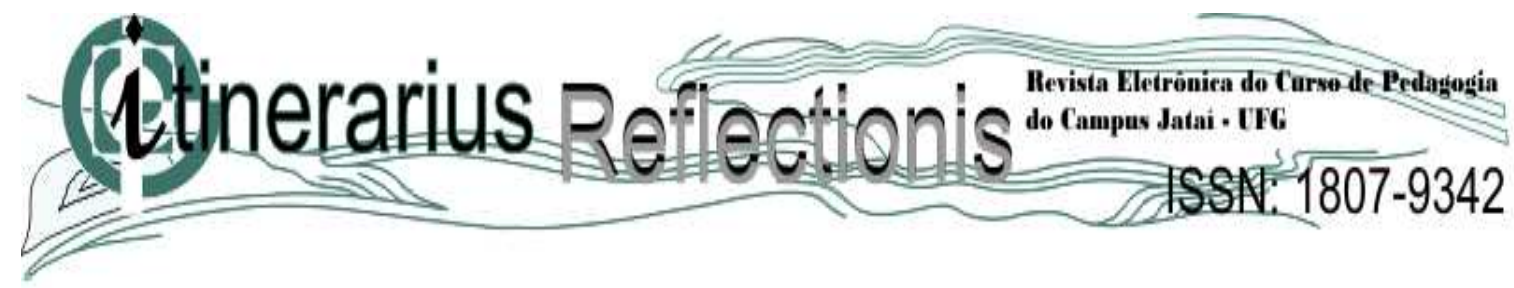

desmatamento, reciclagem do lixo, aquecimento global, etc. Assim a EA é um instrumento que tem como objetivo sensibilizar e provocar mudanças nos alunos, em relação aos hábitos e assumir novas atitudes, porém deve ser lembrando que é um processo permanente, onde todos têm que fazer a sua parte, a administração do colégio, professores, alunos e sociedade.

A EA necessita de tempo para obter resultados, pois é um processo que atua na formação de conhecimentos, hábitos e atitudes do individuo, como foi confirmado por Dias (2004, p. 523) "é um processo permanente [...]” que só tem a contribuir quando a direção do colégio junto com os professores desenvolve estudos e práticas sobre EA, pois assim é possível formar alunos sensibilizados e preocupados com a preservação do meio ambiente. A realização de trabalho interdisciplinar em EA é um caminho para obter os resultados, Desse modo aponta os PCNs (2000) à interdisciplinaridade possibilita uma interação com as demais disciplinas, onde juntas alcança os resultados esperados.

\section{REFERÊNCIAS BIBLIORÁFICAS}

ALVES, Freitas de Silva; OLIVEIRA, Sandra de Fátima. Praticas pedagógicas de Educação Ambiental no ensino de geografia: necessidade de transição de paradigmas. Portal de revista da USP. Ribeirão Preto, v. 3, n. 2, p. 9-24, dez. 2008. Disponível em:

<http://www.revistasusp.sibi.usp.br/pdf/pea/v3n2/02.pdf>. Acesso em: 14 maio 2011.

ALVES, Glória da Anunciação. Cidade, cotidiano e TV. In: CARLOS, Ana Fani

Alessandri(Org.). A geografia na sala de aula. 8. ed. São Paulo: Contexto, 2006. p. 134-144.

BIGOTTO, Antonio Cesar. Educação ambiental e o desenvolvimento de atividades de ensino na escola pública. São Paulo: 2008. 135 f. (Dissertação de mestrado em educação) São Paulo, 2008.

BRASIL. Secretaria de Educação Média e Tecnológica. Ciências humanas e suas tecnologias In:___ Parâmetros Curriculares Nacionais Ensino Médio: Brasília: MEC/SEF, 2000. Disponível em: <http://portal.mec.gov.br/seb/arquivos/pdf/CienciasHumanas.pdf>. Acesso em: 30 out. 2011.

CASTROGIOVANNI, Antônio Carlos et al. (Org.). Ensino de geografia considerações ainda iniciais. In: Ensino de geografia: caminhos e encantos. 2. ed. Porto Alegre: Edipucrs, 2004. p. 16-24. 


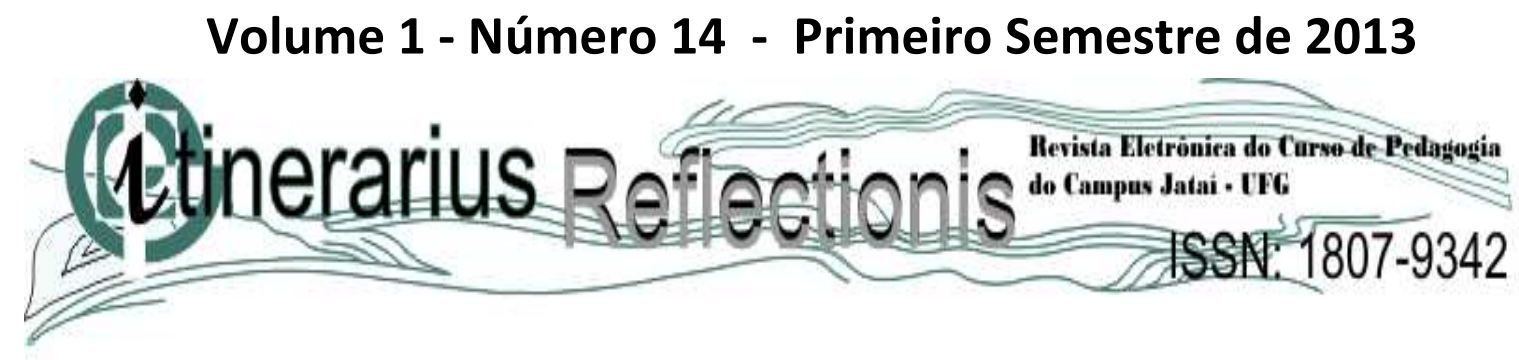

CAVALCANTE, Lana de Souza. Geografia e práticas de ensino. 1. ed. Goiânia: Alternativa, 2002.

DIAS, Genebaldo Freire. Educação: conhecendo o metabolismo da cidade. In:

Educação ambiental: princípios e práticas. 9. ed. São Paulo: Gaia, 2004. p. 287-551.

DIAS, Genebaldo Freire. Subsidio para a prática de educação ambiental. In:

Educação ambiental: princípios e práticas. 9 ed. São Paulo: Gaia, 2004 p. 209-233.

DIAS, Genebaldo Freire. Evolução dos conceitos da EA. In:

Educação ambiental:

princípios e práticas. 5 ed. São Paulo: Gaia, 1998. p. 25-53.

GUIMARÃES, Mauro. A dimensão na educação ambiental. 8. ed. São Paulo: Papius, 1995. $104 \mathrm{p}$.

LÜDKE, Menga; ANDRÉ, Marli E. D. A. Andre. Pesquisa em educação: abordagens qualitativas. São Paulo: EPU, 1986. 99 p.

MAERCHESINI JR., Atílio. O modelo de vida alienante da sociedade do consumo. Revista Eletrônica Ateliê Geográfico, Universidade Federal de Goiás, Goiânia, v. 6, n 2, p.131-147, 2012. Acesso em: 02 out 2012. Disponível: em http://www.revistas.ufg.br/index.php/atelie/article/view/16270/11458

OLIVEIRA, Sandra de Fátima. Educação ambiental pertencer e cuida da teia da vida. Revista Mercator - Revista eletrônica de geografia da UFC, Ceará, v. 07, n. 13, p. 39-46, set 2008. Disponível em: <http://www.mercator.ufc.br/index.php/mercator/article/viewFile/7/3>. Acesso em: 15 abr. 2011.

OLIVEIRA, Thaisa Lemos de Freitas. Concepções e práticas de educação ambiental na rede municipal de ensino de Jataí (GO): conhecimento e sentido produzido por meio de uma pesquisa-ação. Campo Grande (MS) Universidade Federal de Mato Grosso do Sul: 2010. 215 f. ( Dissertação de mestrado ensino de ciências) Campo Grande (MS), 2010.

PEDRINI, Alexandre Gusmão. et al. (Org.). Trajetórias da educação ambiental. In: Educação ambiental: reflexões e práticas contemporâneas. 5 ed. Petrópolis: Vozes, 2002, p. 21-87.

PINESSO, Denise Cristina Christov. A questão ambiental nas series iniciais: prática de professoras dos Distrito Anhanguera - São Paulo. São Paulo (SP) Universidade de São Paulo 


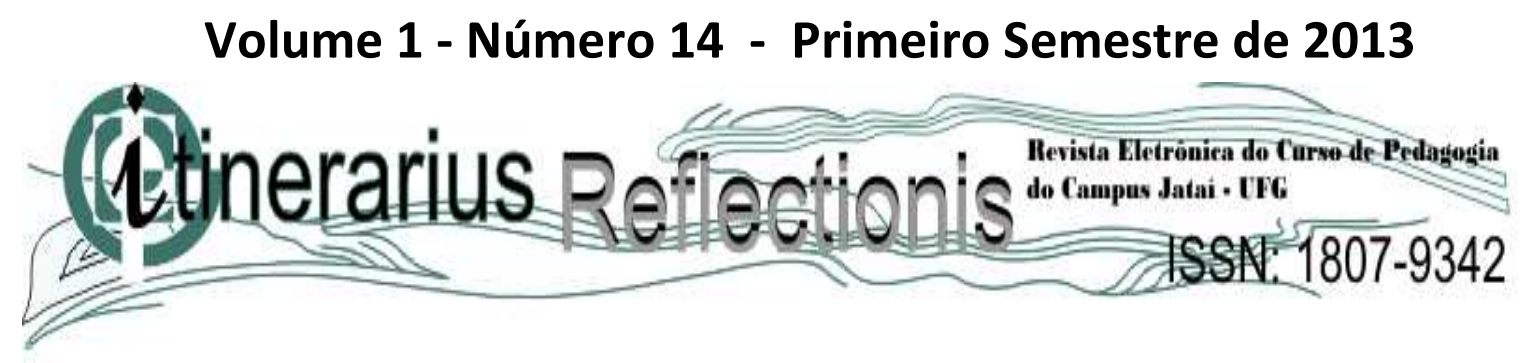

Faculdade de Filosofia, Letras e Ciências Humanas. 2006. 176 f. (Dissertação de mestrado em Geografia) São Paulo (SP) 2006.

REICHWALD, Guilherme Jr; SCHÄFFER, Neiva Otero; KAERCHER, Nestor André. A geografia no ensino médio. In: CASTROGIOVANNI, Antonio Carlos. et al (Org.). Geografia em sala de aula: práticas e reflexões. 4. ed. Porto Alegre: UFRGS/Associação dos Geógrafos Brasileiro, 2003.p.169-172.

TRAVASSOS, Edson Gomes. A prática da educação ambiental nas escolas. 2. ed. Porto Alegre: Mediação, 2006. 88 p.

TOZONI-REIS, Marilia Freitas de Campos. Introdução. In: Educação ambiental natureza, razão e historia. Campinas, SP: Autores associados, 2004. p. 3-25.

ZEPPONE, Rosimeire Maria Orlando. Aspectos pedagógicos da educação ambiental. In: Educação ambiental: teoria e práticas escolares. 1. ed. Araraquara: JM Editora, 1999. p. 25-36.

ZEPPONE, Rosimeire Maria Orlando. Porque focalizar a educação ambiental. In:

Educação ambiental: teoria e práticas escolares. 1. ed. Araraquara: JM Editora, 1999. p. 1723. 